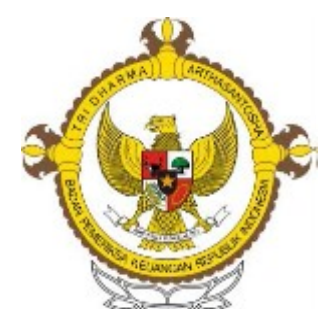

TATA KELOLA DAN AKUNTABILITAS KEUANGAN NEGARA

Volume 6, Number 1, Jan-Jun 2020, 1-18

e-ISSN 2549-452X

p-ISSN 2460-3937

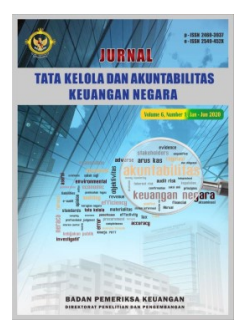

\title{
EXPLAINING EXISTING PERFORMANCE OF INDONESIA'S AUDIT BOARD: INFORMAL NETWORKS, CONSTITUTIONAL MAKERS' DECISION, AND CONSTITUTIONAL REFORM
}

\begin{abstract}
Adfin Rochmad Baidhowah
Policy and Governance Program, Crawford School of Public Policy, Australian National University, Australia

adfin.baidhowah@anu.edu.au

ABSTRACT

This study seeks to explain the process of Audit Board article amendment in the constitutional reform as the source of current BPK's performance, by answering questions: how much do informal networks influence constitutional maker's decision and to what extent do the external pressures influence the informal networks on the amendment of Audit Board article? This study used a quantitative method to develop variables of social networks in examining how much informal networks based on ideational informal networks influence constitutional makers' voting between 1999 and 2001 in six meetings which contained voting out of 39 meetings of the Audit Board article amendment. Illustrating statistically significant results of the influence of ideational informal networks on the constitutional makers' decisions and the influence of high political effect (president's preference) and strong party pressure on the ideational informal networks, this study shows that "the progressive liberal bloc" which can enforce constitutional reform - particularly Audit Board article though not full-scale reform - within the "ineffective formal institution" as it happened in transition era, has shown how informality's outcome is in line with formality's outcome, so it causes improved performance of Audit Board today. Because the statistical evidence talks to broader topics about the people representative bodies and governance, this study suggests paying more attention to the factors of constitutional makers' networks, on and off the meetings of constitutional reform.
\end{abstract}

\section{KEYWORDS:}

Indonesia; state audit board; constitutional maker's networks; constitutional reform 


\section{INTRODUCTION}

Indonesia's Supreme Audit Institution (Badan Pemeriksa Keuangan, BPK) has become a crucial player in the investigation of the Indonesian state budget. All local governments and central government endeavor to obtain BPK's opinion particularly Unqualified Opinion (Wajar Tanpa Pengecualian, WTP) which is the highest opinion, as it shows that the government has been managed accountably. The President of Indonesia in 2019 also gave praise to BPK which was successful to restore Rp4.38 trillion the state's budget and asset (Tempo, 2019). To be sure, these conditions are far better than in the Suharto's era, in which BPK did not function properly (Sesneg, 2009; BPK RI, 2012).

While scholars provide evidence which elucidates the contributor factors of current BPK's performance such as organizational design as a key factor of performance (Pramono, 2016); internal, external, and supporting factors of transformation (Pramono \& Hendharto, 2018); and leadership factors on increasing BPK's audit quality (Komalasari, 2016), few have illustrated evidence from a structural explanation of BPK reform trajectory which happened in Indonesia's transition era 1998-1999.

By drawing on historical institutionalism concept (Hall \& Taylor, 1996), this study argues that current BPK's performance is a direct result of Indonesia's constitution amendment 1999-2002. The constitution amendment has been a critical juncture to the powerless investigation body in the Suharto era to become a functioning one.

There is no claim in this study, that the constitution amendment of BPK article has recreated a perfect BPK today. Instead, this seeks to explain that the constitution amendment process was not failed to create an im- proved BPK, irrespectively the evidence from Baidhowah (2019) who shows that BPK's current condition still inherits issues like in the Suharto's era. Political factions in the People's Consultative Assembly (Majelis Permusyawaratan Rakyat, MPR) - the Work Group Party (Golongan Karya, Golkar), the Nation Awakening Party (Partai Kebangkitan Bangsa, PKB), the Unity and Development Party (Partai Persatuan Pembangunan, PPP), the Moon Star Party (Partai Bulan Bintang, PBB), and the Reformasi - which agreed with the Constitution amendment 1945 had succeeded to force them - the Indonesian Democratic and Struggle Party (Partai Demokrasi Indonesia Perjuangan, PDIP) and the Army/Police (TNI/Polisi) - which did not agree to conduct the reform (King, 2004) - including BPK article though not full-scale reform (Sesneg, 2009; Baidhowah, 2019). Reformasi is consists of the National Mandate Party (PAN) and Justice Party (PK).

Previous research from Baidhowah (2019) has studied the existence and dynamics of informal networks of the constitutional makers within the re-establishment of BPK article in the constitutional reform 1999-2002. By drawing on King's (2004) argument, Baidhowah's (2019) research mapped political factions in the MPR based on informal networks. The informal networks are glued together by ideas of 'the progressive liberal bloc' which prefer reform, and "the conservative statism bloc" which does not prefer reform in creating a winning coalition within the amendment. The ideas are completely influenced by the dynamics of decisions in informal relations among the chiefs of political parties - as elites do matter in Indonesia context - which is then translated into their party's members in formal forum, the MPR.

Drawing on this Baidhowah's (2019) evidence, however, how much they are significant and to what extent the social external pressures play, has never statistically been 
analyzed. Therefore, based on that general overview, this study aims to provide statistical empirical evidence on the question of, by handling issues of non-spuriousness (other independent variables which can influence the outcome), how much do the informal networks influence the constitutional maker's decision and to what extent do the social external pressures put an effect on the ideational informal networks on the amendment of BPK article?

Answering those questions have theoretical and empirical significance, namely, this study complements the previous study to show statistically how much the influence of informal networks on the constitutional makers' decision and put additional information on the social external pressures on the ideational informal networks of the BPK article. In lights of informality in Indonesia is broadly acknowledged, in which it has been studied in the various realms. For one, in the Indonesian context, informality is well documented: for instance, in the social realm "the invocation of social norms, mediation, and the use of social affiliations" have been seen as critical to the construction of the state-citizenship relationships (Berenschot \& van Klinken, 2018). Second, in the religious realm, informal clientelist networks have shaped the way the Indonesian people treat the Ahmadiah group (i.e. heretical religious group) in discriminatory ways (Soedirgo, 2018). Third, in the economic realm, studies have shown how hybrid model influences Jakarta's land transformation, namely blend of neo-liberalization and informal networks of state actors, the development industry, the conglomerates' stand-alone developers and development arms, elite's role, and international business people (Herlambang, Leitner, Tjung, Sheppard, \& Anguelov, 2019). Fourth, in the political context, Aspinall and Berenschot (2019) prove that the current democratic situation Indonesia, particularly in the process of election at local and national le- vels is highly influenced by informal clientelism networks that they categorize as "freewheeling clientelism".

To illustrate these arguments, this section provides subsections which explain about background of Indonesia's constitutional reform and specifically on BPK reestablishment, then moves to construct literature review on informality, formality, and political behavior, before explains how progressive liberal bloc play roles. Subsequently, the second section develops a research method to answer the questions. Lastly, the third section illustrates the results and discussion.

\section{Indonesia's Constitutional Reform 1999-2002 and Re-establishment of BPK}

Constitutional reform, which is "the process of reconstructing the constitution and the laws it governs through public consultation and negotiation" is a way to strengthen governance (Dressel, 2011). There are two parts of constitutional reforms which can determine the quality of good governance, namely the quality of the process (i.e., the more transparent, participatory, and inclusive the process of constitutional document drafting, the more legitimate a political order in exercising good governance); and institutional choices such as degree of decentralization, a form of government, electoral rules, and judicial agencies (Greenberg, Katz, Oliviero, \& Wheatley, 1993; Sunstein, 2001).

Indonesian constitutional reform occurred in 1999-2002 when the country faced a political and economic crisis. In terms of quality of process in the Indonesian constitutional reform, it was conducted in manners of gradualist, with minimal consultation, and dominated by members of parliament (Dressel \& Bunte, 2014; Horowitz, 2013). Moreover, the reform processes lacked some 
key features of the democratic process in making the constitution, such as short-term political interests contaminating the amendment proposals, no clear plan or objective, little public participation, and the MPR failure in its capacity as a constitution maker to win the people's trust (Indrayana, 2005; 2007). Thus, the process of Indonesian constitutional drafting was indeed closedconstitutional drafting.

Based on the principle of total secrecy, the closed-constitutional drafting provides a benefit by improving the discussion among drafters, as it lets them change their thoughts if they are persuaded of the opponent's truth view (Elster, 1993). While openconstitutional drafting, which involves the public, can cause issues of overbidding, grandstanding, and stubbornness (Elster, 1993). However, public participation is essential to ensure a democratic process; and it can ensure people control over the constituent power or as a source of legitimacy (Wheeler, 1961).

The constitution reform of BPK article aims to ensure the quality of state audit institution as an accountability body to ensure the existence of principles of good governance, specifically, accountability, transparency, effectiveness, and the rule of law (Jorgensen \& Sorensen, 2012). The idea for BPK reform was strongly influenced by external actors International Monetary Fund (IMF), World Bank (WB), and Asian Development Bank (ADB) - which gave financial assistance after the end of the Authoritarian New Order period in 1998 (Harun, vanPeursem, \& Eggleton, 2012). The financial assistance obliged Indonesia to reform its fiscal and banking system (Harun et al., 2012; Barclays Economic Review, 1998), in which it required stronger accountability by reforming the audit board (Nasution, 2008; IMF, 1999).
Theoretically, institutions of accountability consist of (i) internal audit institution, or person or division within an institution conducting audit functions; and (ii) external audit institution, or an organization with audit function separate from the institution audited (Hermanson \& Ritterberg, 2003; Skousen Glover, \& Prawitt, 2005; Prawitt, Smith, \& Wood, 2009). In the public sector, external audit institution is manifested into a state audit institution (SAI). SAI is traditionally understood and believed to inquire about the state's institutions to account their budget (OECD, 2016; INTOSAI, 2019). Independence is a prerequisite to be a successful SAI, in which it should be written in a state's constitution (INTOSAI, 2019; The Lima Declaration of 1997). The SAI's independence consists of independence of its members (officials and staff) and financial management; as well as independence from the legislative, executive, and judicative. Additionally, in the constitution, SAI should have investigation power to access all documents and records about financial management. Also, SAI's significant power should be incorporated with transparency, accountability, and ethics, by making its work publicly available, adopting international standards, managing its organizational budget effectively and efficiently, and ensuring its human resource competency, professional secrecy, objectivity, impartiality, and integrity (INTOSAI, 2019).

In Indonesia, in which the SAI is manifested into BPK, it had a legal framework before 2001, which was reflected in section VIII about finance in article 23 (The Constitution 1945). In other words, the BPK article in the Indonesian constitution before the amendment was part of the finance section. The article said that to audit the financial responsibility of the state budget, the state created an audit board which its regulation was established by law. The audit results were reported to the lower house of representatives. 
By contrast, the legal framework for the BPK after 2001 was in the Indonesian constitution, section VIII A about BPK, where it was separated from the section of finance but still related to the finance section (The Constitution 1945 after amendment 1999-2002). Section VIII A consists of three articles and seven paragraphs. Article 1 of such section declares that to audit management and responsibility of state budget, the state creates one free and independent state audit board; the audit results are reported to the upper and lower houses of the representative and local house of the representative; the audit results are followed up by representative institutions and/or relevant agencies based on law. Article 2 of such a section articulates that members of BPK are elected by the lower house of representatives, paying attention to consideration of upper house of representative, and finally the elected BPK members are stipulated by the president; the leader of BPK is elected by the members. Article 3 of such a section declares that BPK is located in the state's capital and has several branches in every province; further provisions about $\mathrm{BPK}$ are regulated by law.

\section{Formality, Informality, and Political Behavior}

Within the constitutional processes, there are aspects of informality and formality which exist and can influence the constitutional drafters' decision. In organization forms, informality and formality consist of unstructured versus structured, unruly versus rule-based, and unpredictable versus predictable (McFarlane, 2012). Formality is a group of individuals who involve within social practices featured by embodied and explicit - "publicly available, ritually accepted, and professionally written" - regulations and rule; then behavior which follows the regulation and rule is formal behavior (Borocz, 2000). On the contrary, informality often plays crucial roles in influencing a processes' outcome such as important performance and sometimes in unexpected ways (Helmke \& Levitsky, 2004). All forms of social groups and actions which constitute the avoidance of the formality definition above are informal groups and behavior (Borocz, 2000).

Informal institutions which are 'socially shared rules, usually unwritten, are created, communicated, and enforced outside of officially sanctioned channels' (Helmke \& Levitsky, 2004), can be identified through three indicators, namely "framework (institutions, organizations, and networks), process (politics, arrangement, and activity), and outcome (rules, norms, and influence)" (Christiansen \& Neuhold, 2012). The three indicators of informal institutions relate to Helmke and Levitsky (2004) argument that in researching informal institutions, several crucial things are needed to analyze: what relevant actors' shared expectations, community, and interests involved; why informal institutions exist; and how informal institutions work.

There are four informal institutions according to Helmke and Levitsky (2004), namely "complementary informal institution" which exists when informality's outcome is in line with formality's outcome within "effective formal institution"; and "accommodating informal institution" which exists when informality's outcome is not in line with formality's outcome within "effective formal institution". Then, "substitutive informal institution" which exists when informality's outcome is in line with formality's outcome within "ineffective formal institution"; and "competing informal institution" which exists when informality's outcome is not in line with formality's outcome within "ineffective formal institution".

Politics which is saturated with informal nuances (Borocz, 2000) can exist in the sphere of constitution-making, because constitution 
-making actors are politicians. Politicians' social environment which explains their characteristics - if the characteristics of two or more politicians are same - can explain whether or not processes of influence (people choosing their friend's preferences) and leverage (people can finish something because they have connections with other relevant actors) exist (Borgatti, Mehra, Brass, \& Labianca, 2009). In the Indonesian constitutional reform context, informality as a framework reasonably exists in networks, namely the informal networks between constitutional drafters in discussing and deciding the BPK article. Similarly, the three indicators of informality as a process exist in the Indonesian constitutional reform. Most constitutional reform drafters are politicians, and the discussion is the politics forum that tries to arrange amendments on the BPK article. Moreover, in terms of informality as an outcome, influence is relevant to the Indonesian constitutional context, namely how informal networks between constitutional drafters constrain and enable the constitutional drafters' behavior.

The most factions in the Indonesian constitutional reform context are political parties, in which they are office-seeker that perform individually to obtain power, income, or prestige which can come by being in an office (Riker, 1962). To achieve the goal, the factions therefore should build coalitions just as big as the factions assure will obtain winning and no bigger. The coalition is minimalwinning which means that the ouster of one faction from that coalition is able to cause loss (Hindmoor \& Taylor, 2004).

Within the coalition dynamics, several policy -seeking behaviors exist (Hindmoor \& Taylor, 2004). First, center parties are "the median parties" which play a crucial role in the formation of the coalition. Without the median parties, a coalition will not achieve a minimum condition to win voting such as a vot- ing system of 50 percent plus one or $2 / 3$. Second, extreme parties are parties that are on the far right and the far left, where extreme parties cannot be included in government as the median parties will calculate that coalitions with the extreme parties are possibly unstable then it cannot produce robust policy implementation. Third, minority administrations exist when "parties are policy-seeker" and there is no possibility for winning coalition then all parties prefer the median party to govern alone. Forth, majority administrations exist when the government is built by a bigger number of parties rather than the minimal-winning coalition. So, additional parties that join with the minimalwinning coalition will not cause a difference in policy implementation and "utility of policy-seeking members".

In Indonesia, the constitutional reform context of BPK article, the policy-seeking behaviors which exist are, first, majority administrations as majority parties build a coalition in terms of agreeing on the idea that BPK article will be reformed. Second, center parties where Golkar, PPP, and PKB which are the median parties play important roles in the dynamic process of constructing the BPK article in different MPR meetings. While extreme administrations do not exist TNI/Polisi as the most conservative will not join with Reformasi as the most progressive; and similarly, because all parties always try to make a coalition and do not let Golkar solely determine the final result of BPK article, so minority administrations in this regard do not exist.

How the politicians choose between choices and behave upon political conditions within the winning-coalition theory is based on rational choice theory (Downs, 1957). Rational politicians should behave through assumptions of "discrete purposeful actor, utility, and rationality": they are always able to decide something when are facing several con- 
strained alternatives, can rank alternative from the highest desired to the lowest one, and always make same decisions when they face the same alternatives (Lovett, 2006).

However, because the existence of informal institutions in various contexts which can construct stronger political outcomes and behavior; and the informal institutions start from norms of the legislature and executive to patrimonialism, clientelism, and oligarchy (Helmke \& Levitsky, 2004), the sense of rational choice does not work anymore, rather the existence of ideational factors will play crucial roles in the political behavior (Ingham, 2012; Campbell, 2004).

Explanations of ideational factors underline the leverage of "nonmaterial, principled ideological commitment" (Ingham, 2012). Several types of ideas can influence as, first, "cognitive paradigms" which exist when "taken-for-granted world views of politicians" can constrain the range of their preferences to consider a decision (Campbell, 2004). Second, "normative ideas" which exist as "taken-for-granted assumptions" in terms of identities, values, attitudes, as well as collective and shared expectation (Katzenstaein, 1996). Third, "programmatic ideas" exist as a guideline on how existing instruments and institutions need to be utilized in particular situations based on "the principles of well-established paradigms" (Hall, 1993).

Therefore, based on this description, winning-coalition under the sense of shared ideas rather than shared rational choice is relevant to analyze informal networks in Indonesian constitutional reform context, as Blair (2004) argues that pragmatic ideas of the constitutional makers' private interest and political interest exist in the constitutional reform process in terms of choosing preferences of state's institutions.
The way in which the political parties move to build winning-coalition depends on their key politicians' decision, in which the existence of the key politicians depends on the degree of distribution of power across political individuals in a community (Winters, 2013). The theory of power resource shows that "we should reverse the behavioral approach and begin the study of power with power resources rather than with exercise of power" (Korpi, 1985). The theory realizes that individuals within a community own several "quantum of power" from lowest to highest, in which the types of the power resources consist of material power which can produce oligarchy, as well as mobilization power, coercive power, official positions, and political rights which can produce elite politics (Winters, 2013). In Indonesia's political context, all types of the power resources exist and have a significant role.

Regarding the Indonesian constitutional reform, mobilization power as elites' capacity to move people in politically formidable strategies (Winters, 2013) is the most relevant power resource which exists. One of the factors which can have this powerful resource is personality (popularity and charisma) connected with his or her people (Poguntke \& Webb, 2005).

Indeed, figures in Indonesia transition from the Suharto's authoritarian era to the Reformasi era play significant rules in the MPR's factions, namely General Wiranto in TNI/ Polisi, Megawati in PDIP, BJ Habibie and Akbar Tanjung in Golkar, Hamzah Haz in PPP, Abdurahman Wahid and Matori A. Djalil in PKB, Amien Rais in Reformasi, and Yusril Mahenda in PBB (Thompson, 1999). Moreover, every party's rule supports this concept of power resource to exist sustainably, as members of MPR factions which are members of political parties, in which every political party's rule regulates that the party's central power is on its chief in terms of 
making a decision, and each member should obey the decision (Statues and By-laws of Political Parties in Indonesia). Therefore, results of the ideational informal networks among the chiefs of political parties ultimately decide where BPK article amendment will go, as the results are translated into their party's members in the formal forum, the MPR.

\section{Achievement of "Progressive Liberal Bloc": Little Result but Meaningful}

The previous subsections of this study have explained background and literature review, also has underlined the source of ideational informal networks that occur first between the chief of political parties then transmits to their members in MPR. In this subsection, this study provides information on how "progressive liberal bloc" which prefers constitutional reform succeed to create a meaningful change. Source of this section is referring to Baidhowah (2019) work who explains how the dynamics of the "progressive liberal and conservative statism bloc" goes, but in this regard, this subsection much underlines how the "progressive liberal bloc" has made a positive difference in pressures of big power of "conservative statism bloc".

Concerning the emergence of reforming the Constitution 1945 as one of the reformation demands, it has caused cleavage within political factions in MPR because of different ideas in seeing that matter. The progressive liberal idea rose on some political factions Golkar, PKB, PPP, PBB, and the Reformasi which supported the idea to reform the Constitution 1945. These political factions then formed a winning coalition based on the ideational informal networks of the progressive liberal idea. Meanwhile, conservative statism idea rose on other political factions PDIP and TNI/Polisi - which preferred to keep the Constitution 1945. These political factions then formed a winning coalition based on the ideational informal networks of the conservative statism idea.

Before coming to the meeting in the first amendment 1999, there was a big movement of PDIP and TNI/Polisi which changed their idea about the constitutional reform by moving to the "progressive liberal bloc". This was influenced by the movement of their chief of a political party who supported President Habibie, in which he declared as the reformist president and amendment of the Constitution 1945 was one of his programs. To be sure, this occurrence benefited "progressive liberal bloc" which enabled MPR to conduct amendment of the Constitution 1945.

In the meetings of MPR to reform the Constitution 1945, all factions tried to use consensus rather than voting, but in the absence of voting, the preference of each faction still could be understood during the discussion session (Horowitz, 2013). Officially MPR factions showed their detailed and reliable indications of which faction supported what in every moment. Moreover, King (2004) argued that the Indonesian constitutional reform processes had been the robust preference on consensual approval for amendment over voting; it was to force the "conservative statism bloc", namely when they did not agree with the "progressive liberal bloc", then the voting strategy would be used. By using this strategy, "progressive liberal bloc" was able to force the amendment - including BPK article. The old BPK article which regulated that to audit the financial responsibility of state budget, the state created an audit board which its regulation was established by law; and audit results were reported to the lower house of representative, was reformed with a new section, namely VIII A which consisted of three articles and seven paragraphs.

The section stipulated BPK as one free and independent body, for sure it becomes a so- 
lution to the issues in the Suharto era. Though it also showed the failure of "progressive liberal bloc", in which the bloc also wanted to erase the supervisory agency of finance and development (Badan Pengawas Keuangan dan Pembangunan, BPKP) and the lower house of representative was not the only body which chooses BPK's members (Sesneg, 2009; BPK RI, 2012; Baidhowah, 2019). Even so, 'progressive liberal bloc' actually has been successful to encourage re-establishment of a new BPK which is far better than in the Suharto and today BPK has shown its better performance on securing state budget.

\section{RESEARCH METHOD}

This study uses archival data from Sesneg (2009) and BPK RI (2012) to analyze the influence of informal networks on the constitutional maker's decision and the extent of the external pressures influence the informal networks to illustrate six meetings which show the existence (the dependent variable) of voting out of 39 meetings in the amendment of BPK article between 1999 and 2001 (see Table 1). The results of the voting show that in the six meetings, there is 25 (59.5\%) vote for agreeing, 3 (7.2\%) abstained, and 14 (33.3\%), in which Golkar as the most interesting faction because never vote for disagreeing.

Table 1. Faction's votes, 1999-2001

\begin{tabular}{lcccc}
\hline & $\begin{array}{c}\text { Vote for } \\
\text { agree }\end{array}$ & Abstained & $\begin{array}{c}\text { Vote for } \\
\text { disagree }\end{array}$ & Total \\
\hline PDIP & 3 & - & 3 & 6 \\
\hline TNI/Polri & 3 & - & 3 & 6 \\
\hline Golkar & 6 & - & - & 6 \\
\hline PKB & 3 & 1 & 2 & 6 \\
\hline PPP & 3 & 1 & 2 & 6 \\
\hline PBB & 4 & - & 2 & 6 \\
\hline Reformasi & 3 & 1 & 2 & 6 \\
\hline Total & $25(59.5 \%)$ & $3(7.2 \%)$ & $14(33.3 \%)$ & 42 \\
\hline Source: developed 6 author based $015 e s n e g(2009)$
\end{tabular}

Source: developed by author based on Sesneg (2009) and BPK (2012)
This study then collects the philosophical viewpoint on the constitutional amendment of the seven political factions in those cases by using social network analysis to capture the ideational informal networks (see Appendix 1). The philosophical viewpoint of those political factions in the amendment of BPK article is really different from the political philosophy in that time, in which PDIP which often confronted with TNI/Polisi in terms of political practice, became a solid coalition in the amendment of BPK article. Moreover, in terms of how the philosophical viewpoint comes up and why the political factions create a winning coalition in MPR meetings of amendment of BPK article, this study refers to the previous work of Baidhowah (2019) who has already analyzed them.

The ideational informal networks as the independent variable are drawn into the adjacency matrix, in which the connectivity of the matrix about the informal networks is $\mathrm{R}$ (idea). Matrix of the informal networks is:

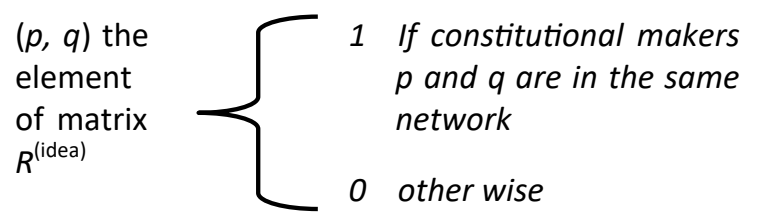

To examine how much the ideational informal networks can influence the constitutional maker's decisions, this study creates two controlling variables to avoid nonspuriousness issues - when the influence for the outcome is not only from the independent variable of interest but from the other variables. The controlling variables are factors of gender and professionalism, in which professionalism can produce independent choice for the constitutional makers. The professionalism consists of, at best, two indicators, namely whether or not the constitutional makers in the political factions are educated and experienced, as Cowton (2009) argues that skill and knowledge based on 
education and experience are the factors of professionalism.

Next, this study creates two additional independent variables to examine to what extent the external pressures influence the ideational informal networks. To capture the pressure, the independent variables are the multiplication between the adjacency matrix $\mathrm{R}$ (idea) and the vector $\mathrm{W}$. Therefore, the proxy of the new social network in this regard is RW.

The external pressure from the president's preference was created, as between 1999 and 2001 was the transition era from Suharto's administration, in which in this era, the president had the biggest power to control all sectors. In other words, in that transition era, the big power of the president position still existed. Besides, the presidents between 1999 and 2001 were the key persons of the political party, namely Habibie as the president in 1999 was the key person of the Golkar along with Akbar Tanjung, then Abdurahman Wahid as the president in 1999 -2000 was the key person of PKB along with Matori Abdul Jalil, and finally, Megawati as the president in 2000-2004 was the key person of PDIP (Thompson, 1999). The other key persons were Hamzah Haz in PPP, Amien Rais in Reformasi, Yusril Mahendra in PBB, and General Wiranto in TNI/Polisi (Thompson, 1999). Moreover, in this regard, the other external pressure from the strong party was created as old political parties which had existed since the Suharto era and even in the election 1999 they were in the top three political parties with the biggest number of seats in the MPR (see Appendix 2).

This study, therefore, operationalizes two hypotheses in terms of the external pressures and provides two additional variables. The first hypothesis argues that the president's preference puts pressures on the ideational informal networks, namely a political fac- tion's vote that understand the vote of the president's political faction through ideational informal networks is more likely to follow the president's preference. The second hypothesizes that strong political factions that have a big number of seats on MPR give pressures on the ideational informal networks, namely a political faction's vote that understand the vote of a strong political faction ideational informal network is more likely to follow the strong political faction. For the first hypothesis, the vector $\mathrm{W}$ is:

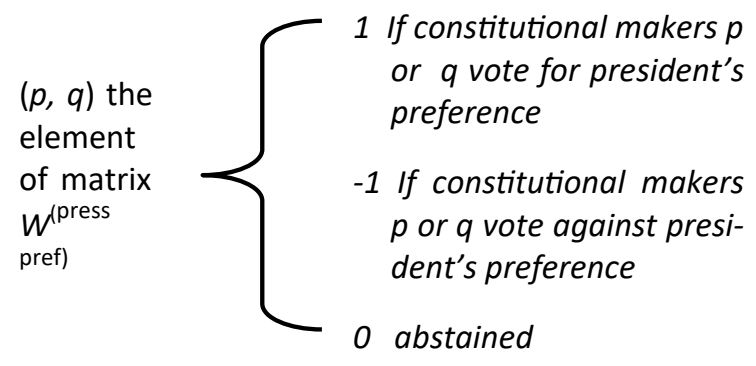

For the second hypothesis, the $\mathrm{W}$ is:

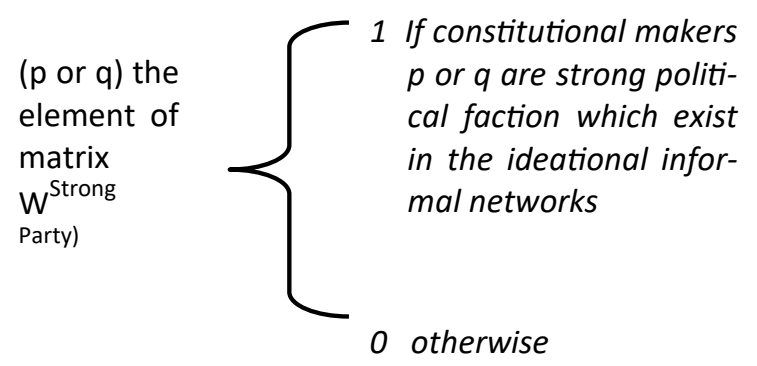

By giving the external pressure of the president's preference on the regression of the ideational informal networks, this study is assessing the political faction's loyalty to the president which is deployed by the president's political faction. Moreover, by giving the external pressure of the strong party on the regression of the ideational informal networks, this study is examining whether the philosophical viewpoint of the constitutional amendment can be disturbed by the rational choice, as shown by Hindmoor and Taylor (2004).

\section{RESULT AND DISCUSSION}

The dependent variable in this study uses score one to agree, minus one for disagree, 
and zero for abstained. Besides, the controlling variables are binary, in which female takes value one and male takes value zero; educated constitutional makers take value 1 and uneducated constitutional makers take value zero, and experienced constitutional makers take value 1 and unexperienced constitutional makers take value zero. Based on the six meetings of constitutional makers' voting between 1999-2001, type of the voting was bloc-voting based on political faction, not individual voting based on individual members of MPR.

Table 2 illustrates the results of how significant the ideational informal networks among the constitutional makers in terms of influencing their decision. In the first model, the coefficient of ideational informal networks shows the positive sign and is significant statistically - significant statistically, if the value of sig. in the table is less than $0.05-$ with adjusted variable 0.842 . The second model which includes the controlling variables shows that coefficient of ideational informal networks is positive and statistically significant $(0.000<0.05)$, while the coefficient of gender as the first controlling variable show positive but not statistically significant (0.627>0.05), and both education and experienced show negative coefficient and not statistically significant (0.745>0.05; $0.745>0.05$ respectively). The adjusted $\mathrm{R}$ square of the second model is 0.838 , which means that these variables in this model explain 83.8 percent of variations. This study then examines the influence of external pressure on the informal social networks by using the additional variables of social networks, namely $\mathrm{R}^{\text {(idea) }} \mathrm{W}^{\text {(press pref) }}$ and $\mathrm{R}^{\text {(idea) }} \mathrm{W}$ (strong party).

Regression results of the social external pressures and ideational informal networks on the constitutional maker's decisions are illustrated in Table 3. Model 1 illustrates the results of the president's preference and model 2 illustrates the results of the strong party effect. The coefficient of $\mathrm{R}^{\text {(idea) }} \mathrm{W}$ (press pref) shows positive sign and statistically significant $(0.038<0.05)$ with adjusted $\mathrm{R}$ square 0.056 , which means that these variables in this model explain 56 percent of variations. Meanwhile, the coefficient of $\mathrm{R}^{\text {(idea) }} \mathrm{W}^{\text {(strong }}$ party) shows positive sign but not statistically significant (0.215>0.05) with adjusted $\mathrm{R}$ square 0.010, which means that these variables in this model explain 10 percent of variations. Those statistical results explain that both models of ideational informal networks with president's preference as the external social pressure and ideational informal networks with strong party effect as the external social pressure increase the possibility of the political factions' voting based on their networks, however the only social networks va-

Table 2. Regression results of the influence of ideational informal networks on the constitutional maker's decisions

\begin{tabular}{|c|c|c|c|c|c|}
\hline & \multirow{2}{*}{ Model } & \multicolumn{2}{|c|}{ Unstandardized Coefficients } & \multirow{2}{*}{ Sig. } & \multirow{2}{*}{$\begin{array}{c}\text { Adjusted R } \\
\text { Square }\end{array}$} \\
\hline & & B & Std. Error & & \\
\hline \multirow[t]{2}{*}{1.} & (Constant) & 1.467 & .029 & .000 & .842 \\
\hline & Ideational Informal Networks & .516 & .029 & .000 & \\
\hline \multirow[t]{5}{*}{2.} & (Constant) & 1.548 & .142 & .000 & .838 \\
\hline & Ideational Informal Networks & .516 & .029 & .000 & \\
\hline & Gender & .031 & .063 & .627 & \\
\hline & Education & -.022 & .069 & .745 & \\
\hline & Experienced & -.022 & .069 & .745 & \\
\hline
\end{tabular}


Table 3. Regression results of the social external pressures and ideational informal networks on the constitutional maker's decisions

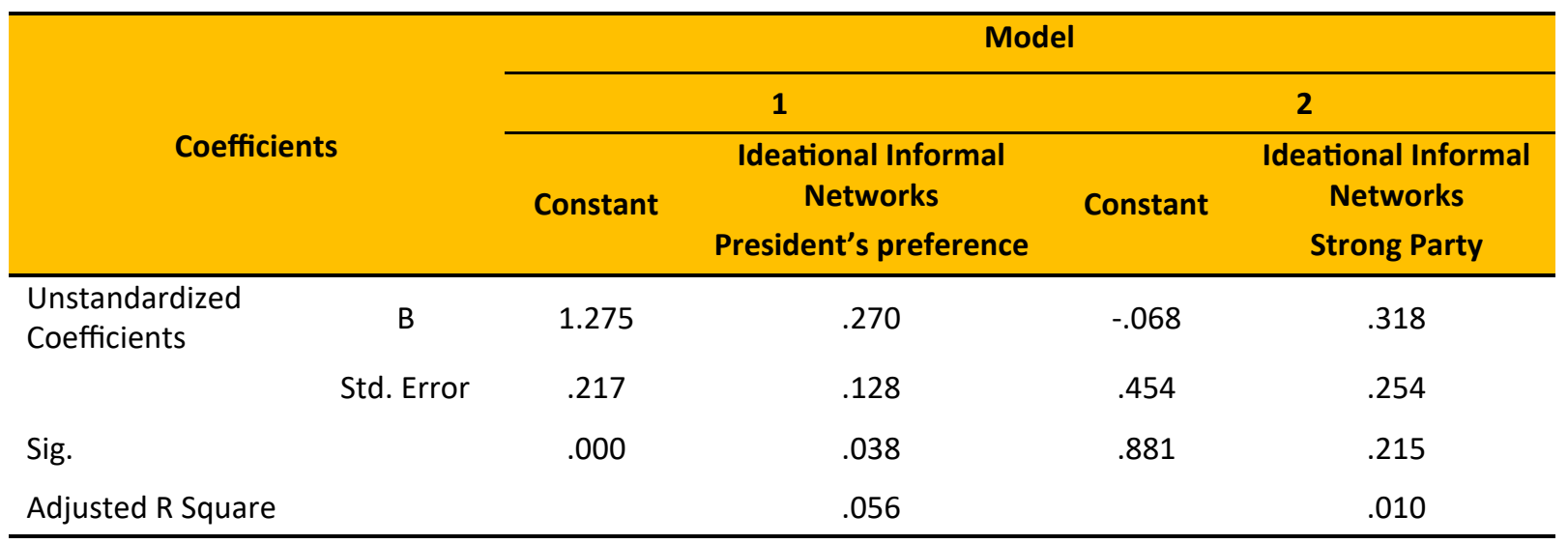

riable which has an influence is the president's preference as the social external pressure in this regard.

These statistical results have illustrated statistically the influence of ideational informal networks on voting behavior by controlling several variables and provided additional information in terms of external pressure on the ideational informal networks. In other words, this study has supported the previous research of Baidhowah (2019) and has provided additional evidence on the social external pressure on social networks.

The examination of the social external pressure also have provided evidence that the conceptual and theoretical framework of rational choice within politics of Hindmoor and Taylor (2004) - political party with a low number of seats in the lower house of representative will move to the high number of seats to build winning-coalition as the seats show the power of a party - really does not exist in Indonesia, especially on the constitutional reform of the BPK article, as evidence of this study shows that the strong party effect is not statistically significant. The examination also brings evidence of the existence of how informality's outcome (ideational informal networks of "progressive liberal bloc") which is in line with formality's outcome (constitutional reform's goal) within 'ineffective formal institution' as the amendment happened in Indonesia's transition era, so it causes improved performance of the Audit Board today.

Finally, these findings recommend that politically informal pressures from the president's preference are crucial elements in deciding where the constitutional maker's decision will go. Moreover, these findings also bring a question up in terms of, to what extent the constitution-makers are independent.

\section{CONCLUSION}

This study tries to explain the process of amendment of BPK article in the constitutional reform as the source of current BPK's performance, by paying attention to how much the informal networks influence the constitutional maker's decision and to what extent the social external pressures put an effect on the ideational informal networks on the amendment of BPK article.

Through the first examination of the independent variable of ideational informal networks, the dependent variable of constitutional maker's voting, and the controlling variables of gender, education, and experi- 
ence on the six meetings which contain voting out of 39 meetings between 1999 and 2001, this analysis illustrates statistical evidence, in which ideational informal networks do shape the patterns of the constitutional maker's voting. Furthermore, based on the second examination of the additional independent variables of social networks, namely social external pressure - president's preference and strong party effect - on the ideational informal networks on the six meetings which contain voting out of 39 meetings between 1999 and 2001, this analysis shows statistical evidence that president's preference and strong party effect through social networks do give an influence on the patterns of the constitutional maker's voting.

These statistical findings provide significant consequences on the theoretical contexts. This study has shown how informality's outcome is in line with formality's outcome within "ineffective formal institution" as the amendment happened in Indonesia's transition era, so it causes improved performance of the Audit Board today. These statistical findings have complemented the previous studies which have mapped the ideational informal networks from "the progressive liberal bloc and the conservative statism bloc" to create a winning coalition within the amendment of BPK article, namely by providing the statistical evidence on the how much the informal networks influence the constitutional maker's decision and put additional information on the extent the social external pressures put an effect on the ideational informal networks. Besides, by providing not statistically significant on the strong party effect and ideational informal networks, this study has proved that rational choice of politics does not work in this regard.

Moreover, this study suggests the next research agenda on informality and constitutional politics. For the first, further research agenda should seek to find an insight from a comparative case study between Indonesia (1999-2002), Thailand (1996-1997), and South Africa (1994-1997) in regards to accountability, where it is crucial for the future of democracy. The further research agenda should analyze doing informal networks work in the constitutional reform in Thailand (1996 -1997) and South Africa (1994-1997)? If so, how their patterns play, and whether it also generates weak provisions.

The reasons for case selections of these comparative studies are that the three countries in those times have faced a transition from authoritarian era to the democratic era and in South Africa, its parliament leads the constitutional reform as a constituent assembly which is similar to MPR in Indonesia (Indrayana, 2005). Thailand and Indonesian constitutional reforms also were caused by economic and political crises. The three countries are developing countries and the three countries which are from Asia and Africa, where that time, the sixth and seventh constitution-making waves happened in both regions (Elster, 1993).

For the second, further research agenda on that comparative studies should engage to the broader networks on and off the meeting of constitution-making such as professional or recruitment, friendship orientation, political orientation, sociocultural orientation, and patronage also clientelism (Dressel, 2019). Finally, based on this study analysis, these findings are hoped will give useful insights to understand political behavior in constitutionmaking.

\section{REFERENCES}

Aspinall, E., \& Berenschot, W. (2019). Democracy for sale: elections, clientelism, and the state in Indonesia. New York: Cornel University Press. 
Baidhowah, A. R. (2019). Crafting a Weak State Audit Board? Evidence from Indonesia's Constitutional Reform (1999-2002). (Unpublished master's thesis). Policy and Governance Program, Crawford School of Public Policy, Australian National University, Canberra, Australia

Barclays Economic Review. (1998). International economy: Asia, second quarter. Barclays Economic Review.

Berenschot, W., \& van Klinken, G. (2018). Informality and citizenship: The everyday state in Indonesia. Citizenship Studies, 22(2), 95-111. doi: 10.1080/13621025.2018.1445494

Blair, A. K. (2004). Empowering the presidency: interests and perceptions in Indonesia's constitutional reforms, 1999-2002. (Unpublished doctoral dissertation). Graduate School of the Ohio State University, Ohio, USA.

Borgatti, S. P., Mehra, A., Brass, D. J., \& Labianca, G. (2009). Network analysis in the social sciences. Science, 323 (5916), 892-895. doi: 10.1126/ science.1165821

Borocz, J. (2000). Informality rules. East European Politics and Societies, 14 (2), 348-380.

BPK RI. (2012). The minutes of the meeting of the Indonesian drafters 1999-2001 for BPK article (Badan Pemeriksa Keuangan dalam proses perubahan Undang-Undang Dasar Negara Republik Indonesia tahun 1945). Jakarta: BPK.

Campbell, J. L. (2004). Ideas, politics, and public policy. Annual Review of Sociology, 28(1), 21-38. doi: 10.1146/ annurev.soc.28.110601.141111

Christiansen, T., \& Neuhold, C. (2012). International handbook on informal governance. Northampton: Edward Elgar.

Cowton, C. J. (2009). Accounting and the ethics challenge: remembering the professional body. Accounting and Business Research, 39(3), 177-189. doi:

10.1080/00014788.2009.9663359

Downs, A. (1957). An economy theory of democracy. New York: Harper \& Row.
Dressel, B. (2011). Strengthening governance through constitutional reform. Philippines: The Governance Brief, Asian Development Bank.

Dressel, B. (2019). The informal dimension of constitutional politics in Asia: insights from the Philippines and Indonesia. in Chen, A. H. Y., \& Harding, A., Constitutional courts in Asia: a comparative perspective (pp.60-87). Cambridge: Cambridge University Press.

Dressel, B., \& Bunte, M. (2014). Constitutional politics in Southeast Asia: From contestation to constitutionalism?. Contemporary Southeast Asia, 36(1), 1-22. doi: 10.1353/ csa.2014.0006

Elster, J. (1993). Constitution-making in Eastern Europe: rebuilding the boat in the open sea. Public Administration: An International Quarterly, 71 (2), 169-217. doi: 10.1111/j.14679299.1993.tboo972.x

Greenberg, D., Katz, S. N., Oliviero, M. B., \& Wheatley, S. C. (1993). Constitutionalism and democracy: Transitions in the contemporary world. Oxford: Oxford University Press.

Hall, P. (1993). Policy paradigms, social learning, and the state: The case of economic policy-making in Britain. Comp. Polit, 25(3), 275-296.

Hall, P., \& Taylor, R. C. R., (1996). Political science and the three new institutionalism. Political Studies, 39(1), 936956.

Harun, H., van Peursem, K., \& Eggleton, I. (2012). Institutionalization of accrual accounting in the Indonesian public sector. Journal of Accounting and Organizational Change, 8(3), 257285. $10.1108 / 18325911211258308$.

Helmke, G., \& Levitsky, S. (2004). Informal institutions and comparative politics: A research agenda. Perspectives on Politics, 2(4), 725-740. doi: 10.1017/ S1537592704040472

Herlambang, S., Leitner, H., Tjung, L. J., Sheppard, E., \& Anguelov, D. (2019). Jakarta's great land transformation: Hybrid neoliberalisation and informality. Urban Studies, 56(4). 627- 
648. doi: $10.1177 / 0042098018$ 756556

Hermanson, D. R., \& Ritterberg, L. E. (2003). Internal audit and organizational governance. Florida: Institute of Internal Auditors Research Foundation.

Hindmoor, A., \& Taylor, B. (2004). Rational choice. New York: Red Globe Press.

Horowitz, D. L. (2013). Constitutional change and democracy in Indonesia. Cambridge: Cambridge University Press.

Indrayana, D. (2005). Indonesian constitutional reform 1999-2002: an evaluation of constitution-making in transition. (Unpublished doctoral dissertation). Faculty of Law, University of Melbourne, Melbourne, Australia.

Indrayana, D. (2007). Amandemen UUD 1945: Antara mitos dan pembongkaran (Amendment of Constitution 1945: between myths and demolition). Bandung, Indonesia: Mizan.

Ingham, M. C. (2012). Crafting courts in new democracies: Ideology and judicial council reforms in Three Mexican States. Comparative Politics, 44(4), 439-458.

International Monetary Fund (IMF). (1999). IMF-supported programs in Indonesia, Korea, and Thailand: a preliminary assessment. Washington DC: International Monetary Fund.

International Standards of Supreme Audit Institutions (INTOSAI). (2019). Towards greater independence - a guidance for supreme audit institutions. Vienna: International Standards of Supreme Audit Institutions.

Jorgensen, T. B., \& Sorensen, D. L. (2012). Code of good governance: national or global public values?. Public Integrity, 15(1), 71-96.

Katzenstaein, P. J. (1996). Introduction: alternative perspectives on national security in the culture of national security: norms and identity in world politics. New York: Columbia University Press.

King, B. A. (2004). Empowering the presidency: interests and perceptions in
Indonesia's constitutional reforms, 1999-2002. (Unpublished doctoral dissertation). Graduate School of the Ohio State University, Ohio, USA.

Komalasari, N. (2016). Does the rotation of head of audit office across offices impact audit quality? Study case of the Audit Board of Republic of Indonesia. Jurnal Tata Kelola dan Akuntabilitas Keuangan Negara, 2(2), 137-150.

Korpi, W. (1985). Developments in the theory of power and exchange. Sociological Theory, 3(2), 31-45.

Lovett, F. (2006). Rational choice theory and explanation. Rationality and Society, 18(2), 237-272. doi: 10.1177/1043463106060155

McFarlane, C. (2012). Rethinking informality: Politics, crisis, and the city. Planning Theory \& Practice, 13(1), 89108. 10.1080/14649357.2012.649951

Nasution, A. (2008). Reforming the state and local government financial management (perbaikan keuangan negara dan daerah). Jakarta: The State Audit Board.

Organisation for Economic Co-operation and Development (OECD). (2016). Supreme audit institutions and good governance: Oversight, insight, and foresight. Paris: OECD Public Governance Reviews.

Poguntke, T., \& Webb, P. (2005). The presidentialization of politics in democratic societies: A framework analysis. Oxford: Oxford University Press.

Pramono, A. J. (2016). Analisis faktor-faktor yang mempengaruhi transformasi kapabilitas organisasi dan peran Badan Pemeriksa Keuangan RI. Jurnal Tata Kelola dan Akuntabilitas Keuangan Negara, 2(2), 175-193.

Pramono, A. J., \& Hendharto, H. (2018). Asumsi kegiatan strategi untuk roadmap transformasi Badan Pemeriksa Keuangan Republik Indonesia. Jurnal Tata Kelola dan Akuntabilitas Keuangan Negara, 4(1), 1-22.

Prawitt, D. F., Smith, J. S., \& Wood, D. A. (2009). Internal audit quality and earnings management. The Accounting Review, 84(4), 1255-1280. doi: 10.2308/accr.2009.84.4.1255 
Riker, W. (1962). Theory of political coalitions. New Haven: Yale University Press.

Sekretariat Negara Republik Indonesia (Sesneg) (State Secretary of Republic of Indonesia). (2009). Kumpulan risalah perubahan Undang-Undang Dasar Negara Republik Indonesia tahun 1945 bidang legislatif (The Minutes of the Meetings of Indonesian Drafters 1999-2002). Jakarta: Sekretariat Negara Republik Indonesia.

Skousen, K. F., Glover, S. M., \& Prawitt, D. F. (2005). An introduction to corporate governance and the SEC. Australia: Cengage Learning.

Soedirgo, J. (2018). Informal networks and religious intolerance: How clientelism incentivizes the discrimination of the Ahmadiyah in Indonesia. Citizenship Studies, 22(2). 191-207. doi: 10.1080/13621025.2018.1445490

Sunstein, C. R. (2001). Designing democracy: What constitutions do. Oxford: Oxford University Press.

Tempo. (2019, August 16). Jokowi apresiasi kinerja BPK, pengamat: tak perlu dipuji (Jokowi appreciates BPK's performance, observer: no need to be praised). Tempo. Retrieved from https://bisnis.tempo.co/read/ 1236651/jokowi-apresiasi-kinerjabpk-pengamat-tak-perlu-dipuji/ full\&view $=$ ok.

The Indonesian Constitution. (1945). Retrieved from United Nations Educational, Scientific, and Cultural Organisation http://www.unesco.org/education/edurights/media/docs/ b1ba8608010ceoc48966911957392ea 8cda405d8.pdf.

The Jakarta Post. (1999). Election 99. The Jakarta Post. Retrieved from http:// www.thejakartapost.com:8890/ elec99.htm.

The Lima Declaration. (1997). Declaration of strengthening supreme audit institutions. Lima: International Standards of Supreme Audit Institutions.

Thompson, E. C. (1999). Indonesia in transition: the 1999 presidential elections. Washington DC: The National Bureau of Asian Research. Retrieved from http://profile.nus.edu.sg/fass/ socect/Thompson\%201999\% 20NBR\%20Briefing.pdf.

Wheeler, J. P. (1961). Salient issues of constitutional revision. New York: National Municipal League.

Winters, J. A. (2013). Oligarchy and democracy in Indonesia. Southeast Asia Program Publications at Cornell University, 1(96), 11-33.

\section{APPENDICES}

Appendix 1. Vote and Existence of Informal Networks

First amendment-Meeting 1 (6 October 1999)

\begin{tabular}{lccccccc}
\hline & PDIP & Golkar & PKB & PBB & PPP & TNI/Polisi $\begin{array}{c}\text { Reformasi } \\
\text { (PAN\&PK) }\end{array}$ \\
\hline PDIP & - & 1 & 1 & 1 & 1 & 1 & 0 \\
\hline Golkar & 1 & - & 1 & 1 & 1 & 1 & 0 \\
\hline PKB & 1 & 1 & - & 1 & 1 & 1 & 0 \\
\hline PBB & 1 & 1 & 1 & - & 1 & 1 & 0 \\
\hline PPP & 1 & 1 & 1 & 1 & - & 1 & 0 \\
\hline TNI/Polisi & 1 & 1 & 1 & 1 & 1 & - & 0 \\
\hline Reformasi (PAN\&PK) & 0 & 0 & 0 & 0 & 0 & 0 & - \\
\hline
\end{tabular}

Source: developed by author based on Sesneg (2009) and BPK (2012) 
First amendment-Meeting 2 (16 October 1999)

\begin{tabular}{|c|c|c|c|c|c|c|c|}
\hline & PDIP & Golkar & PKB & PBB & PPP & TNI/Polisi & $\begin{array}{l}\text { Reformasi } \\
\text { (PAN\&PK) }\end{array}$ \\
\hline PDIP & - & 0 & 0 & 0 & 0 & 1 & 0 \\
\hline Golkar & 0 & - & 0 & 1 & 0 & 0 & 1 \\
\hline PKB & 0 & 0 & - & 0 & 1 & 0 & 0 \\
\hline PBB & 0 & 1 & 0 & - & 0 & 0 & 1 \\
\hline PPP & 0 & 0 & 1 & 0 & - & 0 & 0 \\
\hline TNI/Polisi & 1 & 0 & 0 & 0 & 0 & - & 0 \\
\hline Reformasi (PAN\&PK) & 0 & 1 & 0 & 1 & 0 & 0 & - \\
\hline
\end{tabular}

Source: developed by author based on Sesneg (2009) and BPK (2012)

Second amendment-Meeting 1 (16 February 2000)

\begin{tabular}{lccccccc}
\hline & PDIP & Golkar & PKB & PBB & PPP & TNI/Polisi $\begin{array}{c}\text { Reformasi } \\
\text { (PAN\&PK) }\end{array}$ \\
\hline PDIP & - & 0 & 0 & 0 & 0 & 1 & 0 \\
\hline Golkar & 0 & - & 1 & 1 & 1 & 0 & 1 \\
\hline PKB & 0 & 1 & - & 1 & 1 & 0 & 1 \\
\hline PBB & 0 & 1 & 1 & - & 1 & 0 & 1 \\
\hline PPP & 0 & 1 & 1 & 1 & - & 0 & 1 \\
\hline TNI/Polisi & 1 & 0 & 0 & 0 & 0 & - & 0 \\
\hline Reformasi (PAN\&PK) & 0 & 1 & 1 & 1 & 1 & 0 & - \\
\hline
\end{tabular}

Source: developed by author based on Sesneg (2009) and BPK (2012)

Second amendment-Meeting 2 (19 June 2000)

\begin{tabular}{|c|c|c|c|c|c|c|c|}
\hline & PDIP & Golkar & PKB & PBB & PPP & TNI/Polisi & $\begin{array}{l}\text { Reformasi } \\
\text { (PAN\&PK) }\end{array}$ \\
\hline PDIP & - & 1 & 0 & 0 & 0 & 1 & 0 \\
\hline Golkar & 1 & - & 0 & 0 & 0 & 0 & 0 \\
\hline PKB & 0 & 0 & - & 1 & 1 & 0 & 1 \\
\hline PBB & 0 & 0 & 1 & - & 1 & 0 & 1 \\
\hline PPP & 0 & 0 & 1 & 1 & - & 0 & 1 \\
\hline TNI/Polisi & 1 & 0 & 0 & 0 & 0 & - & 0 \\
\hline Reformasi (PAN\&PK) & 0 & 0 & 1 & 1 & 1 & 0 & - \\
\hline
\end{tabular}

Source: developed by author based on Sesneg (2009) and BPK (2012) 
Third amendment-Meeting 1 (19 September 2001)

\begin{tabular}{lccccccc}
\hline & PDIP & Golkar & PKB & PBB & PPP & TNI/Polisi $\begin{array}{c}\text { Reformasi } \\
\text { (PAN\&PK) }\end{array}$ \\
\hline PDIP & - & 0 & 0 & 0 & 0 & 1 & 0 \\
\hline Golkar & 0 & - & 1 & 1 & 1 & 0 & 1 \\
\hline PKB & 0 & 1 & - & 1 & 1 & 0 & 1 \\
\hline PBB & 0 & 1 & 1 & - & 1 & 0 & 1 \\
\hline PPP & 0 & 1 & 1 & 1 & - & 0 & 1 \\
\hline TNI/Polisi & 1 & 0 & 0 & 0 & 0 & - & 0 \\
\hline Reformasi (PAN\&PK) & 0 & 1 & 1 & 1 & 1 & 0 & - \\
\hline
\end{tabular}

Source: developed by author based on Sesneg (2009) and BPK (2012)

Third amendment-Meeting 2 (6 November 2001)

\begin{tabular}{|c|c|c|c|c|c|c|c|}
\hline & PDIP & Golkar & РКB & PBB & PPP & TNI/Polisi & $\begin{array}{l}\text { Reformasi } \\
\text { (PAN\&PK) }\end{array}$ \\
\hline PDIP & - & 1 & 0 & 0 & 0 & 1 & 0 \\
\hline Golkar & 1 & - & 0 & 0 & 0 & 1 & 0 \\
\hline PKB & 0 & 0 & - & 1 & 1 & 0 & 1 \\
\hline PBB & 0 & 0 & 1 & - & 1 & 0 & 1 \\
\hline PPP & 0 & 0 & 1 & 1 & - & 0 & 1 \\
\hline TNI/Polisi & 1 & 1 & 0 & 0 & 0 & - & 0 \\
\hline Reformasi (PAN\&PK) & 0 & 0 & 1 & 1 & 1 & 0 & - \\
\hline
\end{tabular}

Source: developed by author based on Sesneg (2009) and BPK (2012)

Appendix 2. Indonesia's Election 1999

(in millions)

\begin{tabular}{lccc}
\hline Political Party & Popular Vote & $\begin{array}{c}\text { Seats in Lower House of } \\
\text { Representative }\end{array}$ & Seats in MPR \\
\hline PDIP & 35.7 & 153 & 185 \\
\hline Golkar & 23.7 & 120 & 181 \\
\hline PKB & 11.3 & 58 & 70 \\
\hline Reformasi (PAN, PK) & 13.3 & 51 & 57 \\
\hline PBB & 7.5 and 1.4 & 34 and 7 & 48 \\
\hline TNI/Polisi & N/A & 38 & 38 \\
\hline
\end{tabular}

Source: The Jakarta Post (1999)

NOTES:

1 : same vote and there is an informal network;

0 : different vote and there is no informal network;

: not applicable

PDIP : Indonesian Democratic and Struggle Party

Golkar: Work Group Party
PKB : Nation Awakening Party

PPP : Unity and Development Party

PBB : Star-Moon Party

Reformasi: consists of National Mandate Party (PAN) and Justice Party (PK)

TNI/Polisi : Army/Police 